\title{
Ontario health records proposal would breach privacy, experts say
}

$\mathrm{T}$ he province of Ontario is contemplating the creation of electronic health records that could include a patient's psychosocial, financial and legal history, a provincial official has indicated.

But so comprehensive and sweeping is the proposed database that privacy and legal experts say they are "appalled" and "stunned."

The province's plans, sketched at an ehealth conference in Toronto, Ontario in June by Grant Gillis, director of ehealth standards for eHealth Ontario, would see the creation of comprehensive profiles about all Ontario patients, including their "social history."

The records could include information about a patient's education, employment, financial status, legal history, residence history, sexual orientation and spirituality, Gillis told the conference. Gillis also indicated that the information could include a category called "risk." eHealth Ontario later indicated in an email that "risk is a 'general' category. Some examples found on forms provided by stakeholders during our engagement process include: Risk of falls/wandering; Risk of harm to others; (and) Risk of patient having perhaps been exposed to an infectious disease."

The aim is to create "an overall clinical information model for Ontario," Gillis said.

In response to an inquiry about the appropriateness of including some manner of legal and psychological risk profile in the health profiles of the province's 13 million residents, Gillis said the risk category was included in the template after early consultations with clinicians and other stakeholders. $\mathrm{He}$ added that access to the records would be carefully controlled by stateof-the-art computer confidentiality barriers, and that information included in the social history category of the electronic health records would not necessarily be

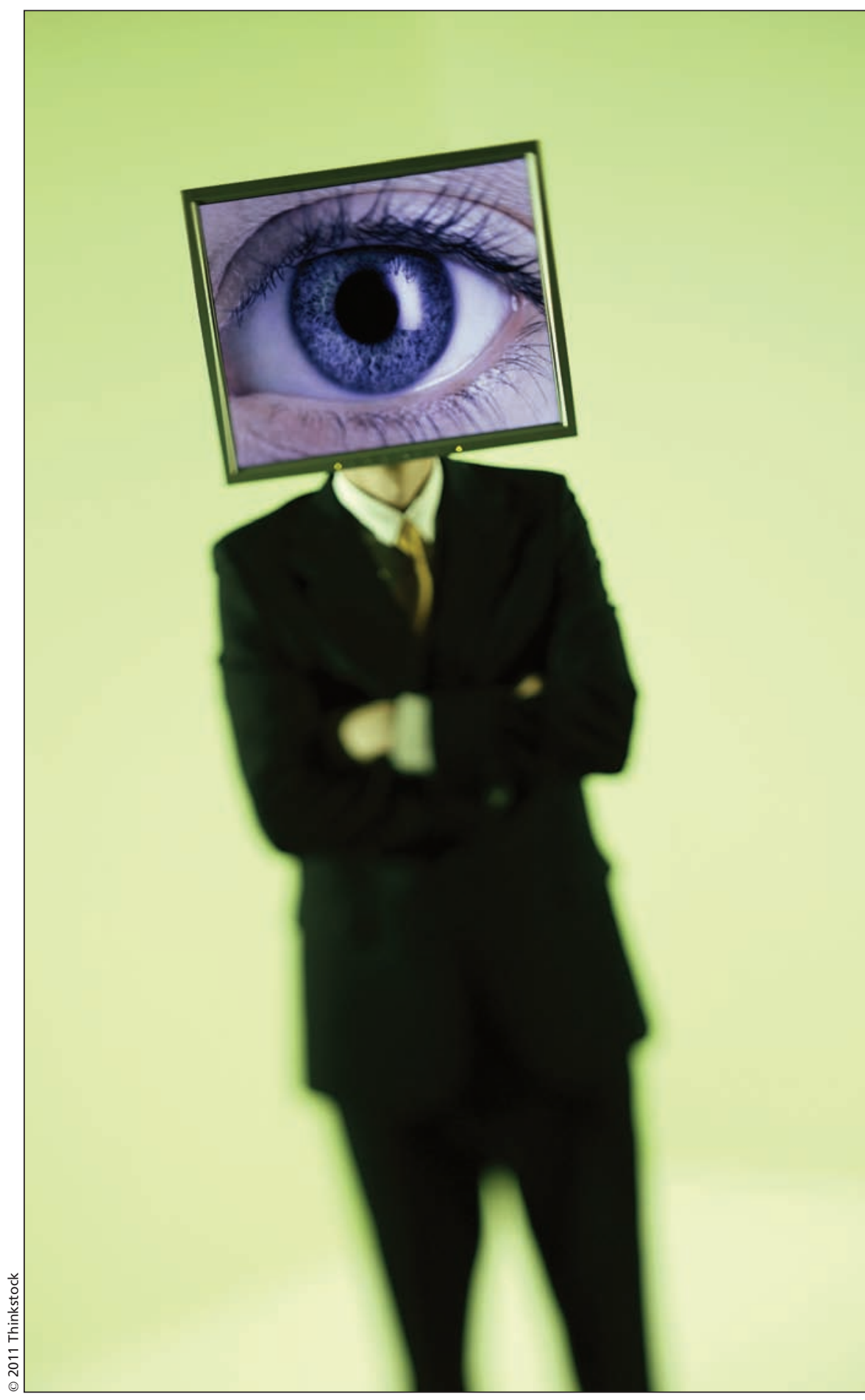

Ontario is proposing to create electronic health records that contain information about a patient's education, employment, financial status, legal history, residence history, sexual orientation, spirituality and other psychosocial traits. 
accessible to everyone. Only "authorized persons" would likely have the right to access parts of the health record containing sensitive information about a patient's risk assessment or legal history, he said.

The latter reassurance is unconvincing, says Khaled el Eman, Canada research chair in electronic health information at the University of Ottawa's Faculty of Medicine in Ontario.

The notion of huge government patient health databases that include psychosocial profiles is highly problematic, he says. "A big concern would be how this data would be used or disclosed for secondary purposes once it is collected. This is not an issue that is being discussed, but once the data is there, it can be used [in] many unantici- pated ways and it is not clear what controls there would be on these secondary uses and disclosures, if any. Should one go by precedent, there may not be many constraints or controls."

The government must clarify who will have access to the electronic health records, el Eman adds. "I think if this information is collected, patients would expect it to be available only to their treating physician. If it is available at tens of thousands of points of care then I think that would erode public trust in EHRs/EMRs pretty quickly. That is, if the public is actually informed about this. But then it will take just a few data breaches or misuses for the story to come out." (Editor's note: Canada Health Infoway views the concept of electronic health records or EHRs as being com- pletely distinct from electronic medical records or EMRs. The former refers to the national electronic architecture, says the agency, which argues that the development of an "interoperable" national infostructure is its primary responsibility. When completed, that national architecture would primarily be used to aggregate health information in such a way that it would be valuable for policy-makers and researchers. The latter concept, EMRs, by contrast, is seen as recordkeeping systems at the doctor-patient level that would be used primarily as an aid in the clinical diagnosis and treatment of disease).

Information and Privacy Commissioner of Ontario Ann Cavoukian said in a statement prepared for $C M A J$ that she has contacted Greg Reed, CEO of

Editor's note: Twenty-second in a series on electronic health records

Part I: Canada's electronic health records initiative stalled by federal funding freeze (www.cmaj.ca/lookup/doi/10.1503/cmaj.109-3183)

Part II: Ontario's plan for electronic health records is at risk, official says (www.cmaj.ca/lookup/doi/10.1503/cmaj.109-3193)

Part III: Electronic health records a "strong priority" for US government (www.cmaj.ca/lookup/doi/10.1503/cmaj.109-3218)

Part IV: The pocketbook impact of electronic health records: PRO (www.cmaj.ca/lookup/doi/10.1503/cmaj.109-3225)

Part V: The pocketbook impact of electronic health records: CON (www.cmaj.ca/lookup/doi/10.1503/cmaj.109-3226)

Part VI: National standards for electronic health records remain remote (www.cmaj.ca/lookup/doi/10.1503/cmaj.109-3239)

Part VII: National electronic health records initiative remains muddled, auditors say (www.cmaj.ca/lookup/doi/10.1503/cmaj.109-3242)

Part VIII: New electronic health record blueprint to call for increased patient participation (www.cmaj.ca/lookup/doi/10.1503/cmaj.109-3265)

Part IX: Albertans to gain electronic access to personal health files (www.cmaj.ca/lookup/doi/10.1503/cmaj.109-3270)

Part X: Canadian hospitals make uneven strides in utilization of electronic health records (www.cmaj.ca/lookup/doi/10.1503/cmaj.109-3288)

Part XI: United States to compel physicians to make "meaningful use" of electronic health records (www.cmaj.ca/lookup/doi/10.1503/cmaj.109-3361)

Part XII: Canada's ehealth software “Tower of Babel” (www.cmaj.ca/lookup/doi/10.1503/cmaj.109-3717)

Part XIII: National electronic health information strategy needs to be refocused, critics say (www.cmaj.ca/lookup/doi/10.1503/cmaj.109-3744)

Part XIV: Seeing is Belizing (www.cmaj.ca/lookup/doi/10.1503/cmaj.109-3782)

Part XV: Experts call for health infoway “watchdog” (www.cmaj.ca/lookup/doi/10.1503/cmaj.109-3783)

Part XVI: Infoway tacks towards “networked” patients (www.cmaj.ca/lookup/doi/10.1503/cmaj.109-3798)

Part XVII: Medical data debates: Big is better? Small is beautiful? (www.cmaj.ca/lookup/doi/10.1503/cmaj.109-3799)

Part XVIII: Audit concludes Infoway missed performance targets (www.cmaj.ca/lookup/doi/10.1503/cmaj.109-3860)

Part XIX: Go local, European review of electronic health records advises (www.cmaj.ca/lookup/doi/10.1503/cmaj.109-3861)

Part XX: Administrator urges penalties for doctors who don't use electronic medical records (www.cmaj.ca/lookup/doi/10.1503/cmaj.109-3914)

Part XXI: Curricula reform needed to develop more tech-savvy physicians (www.cmaj.ca/lookup/doi/10.1503/cmaj.109-3913) 
eHealth Ontario, to discuss the proposed health records. "He assured me that they will be consulting with my office on possible data fields that practitioners have expressed interest in," Cavoukian writes. "Nothing will be finalized until my office and other privacy specialists are consulted. One thing is clear - patient privacy must be directly embedded into the design of our electronic health records from the outset, not as an afterthought."

The rationale for including a patient's legal history in the records and an ill-defined category for "risk" is confounding, says Michael Power, a lawyer who served as vice president for privacy and security for eHealth Ontario between 2007 and 2009.

Power was "stunned" to learn of the proposed information categories and is unconvinced that access will be limited to those with a need to know. "The system is designed to provide the maximum access to the maximum numbers of persons."

The data to be included in EHRs is "the thin end of the wedge of a much larger question," Power adds. "That question is whether these records are appropriate at all."

Comprehensive EHRs available province- and nation-wide would have limited, if any, value to clinicians, whose essential needs are basic health information about the patient and his condition, Power argues. "What governments are building doesn't match the needs of health care providers. ... It feels like a white elephant."

Integrated records delivering aggregated health and social data to a large number of care providers are attracting growing criticism from health ethicists (www.cmaj.ca/lookup/doi/10.1503/cmaj .109-3799).

Inclusion of "social history" information about patients within electronic health records is "very worrying," says Trisha Greenhalgh, director of the Healthcare Innovation and Policy Unit at the London School of Medicine and Dentistry in the United Kingdom.

Information about medication, allergies and adverse reactions represent the "hard" or codifiable end of the data spectrum within EHRs but eHealth Ontario's social history category clearly "includes material that is 'soft,' contextdependent and potentially contestable," she says.

In the UK, there has been a backlash to government efforts to introduce records containing extensive personal profiles, Greenhalgh says.

eHealth Ontario conducted public consultations on its specifications for the new health records last January and published a list of parties who responded. Those included some health institutions and technology companies but not legal, privacy or civil rights experts (www .ehealthontario.on.ca/programs/clinical Document.asp).

The Office of the Information and Privacy Commissioner/Ontario was not aware of the consultations at the time, spokesman Angus Fisher says.

Nor had el Eman heard of the consultations. "I would be surprised if there was a real public consultation that no legal and civil liberty groups would have responded or reacted," he says. - Paul Christopher Webster, Toronto, Ont.

CMAJ 2011. DOI:10.1503/cmaj.109-3917 